Cahiers $d u$ MONDE RUSSE

\section{Cahiers du monde russe}

Russie - Empire russe - Union soviétique et États indépendants

52/2-3 | 2011

L'URSS et la Seconde Guerre mondiale

\title{
How to wage warfare without going to war?
}

Stalin's 1939 war in the light of other contemporary aggressions

Comment faire la guerre sans y aller?. La guerre de 1939 de Stalin vue à travers le prisme des autres agressions contemporaines

\section{Sabine Dullin and Susan Pickford}

\section{(2) OpenEdition}

\section{Journals}

Electronic version

URL: https://journals.openedition.org/monderusse/9331

DOI: 10.4000/monderusse.9331

ISSN: $1777-5388$

Publisher

Éditions de l'EHESS

Printed version

Date of publication: 15 November 2011

Number of pages: $221-243$

ISBN: $978-2-7132-2352-5$

ISSN: $1252-6576$

\section{Electronic reference}

Sabine Dullin and Susan Pickford, "How to wage warfare without going to war?", Cahiers du monde russe [Online], 52/2-3 | 2011, Online since 12 September 2014, connection on 03 September 2022. URL: http://journals.openedition.org/monderusse/9331; DOI: https://doi.org/10.4000/monderusse. 9331 


\title{
HOW TO WAGE WARFARE WITHOUT GOING TO WAR?
}

\author{
Stalin's 1939 war in the light \\ of other contemporary aggressions*
}

Three events took place on the western borders of the USSR in $1939^{1}$. At the time, they were described respectively as an invasion in the case of eastern Poland, a war in the case of Finland, and a military occupation in the case of the Baltic states, later becoming territorial annexations. Official Soviet rhetoric - widely adopted in updated form in modern-day Russia - justified the three events as the accomplishment of the Ukrainian, Belarusian, and Lithuanian national projects, together with the necessary revision of the Treaty of Riga, support for Communist Finland to ensure the safety of Leningrad, and the joint defence of the Baltic coastline by Soviet and Baltic troops. Many historians, while not espousing the latter view, point to the polysemy of the events of autumn 1939: their outcome could not be foreseen by the Polish border guards taken unawares by the arrival of

\footnotetext{
* A shorter version of this paper was presented at the conference "The USSR and World War II" in Paris, May 2011. My thanks to Silvio Pons and Sergei Slutch and to the audience for their stimulating questions and remarks. Thanks also to Sophie Cœuré and the two anonymous readers for their helpful comments on earlier drafts of this article.

1. See M.I. Meltiukhov, Upushchennyi shans Stalina: Sovetskii Soiuz i bor'ba za Evropu 1939-1941 gg. (M.: Veche, 2002); Alfred Erich Senn, Lithuania 1940: Revolution from Above (Amsterdam - New York: Rodopi, 2007); Sławomir Dębski, Między Berlinem a Moskzą, Stosunki niemiecko-sowieckie 1939-1941 (Warsaw: Polski Instytut Spraw Międzynarodozych, 2007). The Winter War has proved of considerable interest to Russian and Finnish historians, who have studied the event from a diplomatic and military perspective in a number of joint publications. The leading experts in the field contributed to the collection of essays Zimniaia Voina 1939-1940: Politicheskaia Istoriia, O. Rzheshevskii, O. Vekhvilainen, eds. (M.: Nauka, 1999), with essays by the Russian historians V. Baryshnikov and O. Rzheshevskii and the Finnish scholars T. Vikhavainen and O. Manninen. The same cannot be said for the history of the occupation of the Baltic states, where there is still too much conflict at national level for a shared historiography to have emerged, except in Lithuania: see Arvydas Anusauskas and Ceslovas Laurinavicius, Lietuva antrajame pasauliniame kare (Vilnius, 2007).
} 
the Red Army, nor by the Baltic leaders who were hoping that bowing to Moscow's ultimatums would ensure their independence, let alone by the Western powers keen to drive a wedge between Stalin and Hitler.

Western historiography often chooses to approach the annexations of 1939-40 by considering them as the matrix for how the territories were organised in the post-war period ${ }^{2}$ and as signs indicating the re-inscription of Stalinist policy in the long view of the history of the Russian power and its geo-political dimension. Historians of the Molotov-Ribbentrop Pact still debate the extent to which Stalin saw it as a defensive policy: was the aim to delay war in the east once Poland had refused to allow the Red Army to pass through the country against a backdrop of deep Russian suspicion of the West's intentions, or was it a strategy to exhaust Europe's imperialist powers, paving the way for the Socialist revolution?

My own approach differs somewhat. I begin by asking two questions: Why did the USSR not become involved in the Second World War from autumn 1939, while waging its own wars? Why did France and Britain not declare war on the Soviets when the Red Army crossed the Polish border? The answers lie in breaking down the barriers between diplomatic and military histories of the USSR and reading Stalin's discourse and practices in autumn 1939 in the wider European context of external policies of intervention and aggression. My initial hypothesis posits the existence of a repertoire and interpretative frameworks that could be described as transnational insofar as they were widely shared and used among leaders of the time - politicians and experts in international relations. The Soviet leaders and their European counterparts each had their own cultural and political references and their own particular approaches to national interest: however, they were also deeply involved in the problematics that had arisen from aggression, appeasement, and collective security since the previous war, particularly in terms of practices that were in line with or against League of Nations policy. Furthermore, the legal debate over "crimes against peace" that was later to take place in Nuremberg drew on arguments developed in the late 1930s, particularly by Soviet legal scholars. ${ }^{3}$ Though the League of Nations had lurched from one failure to another from the mid-1930s on, it still remained the key reference for public opinion in 1939, particularly in Europe.

I think it is important in explaining the significance of the moment of $1939^{4}$ in the history of international relations not to draw on hindsight in judging the failure of the League of Nations, the pact, the division of Poland and the Winter War: rather, historians should stick to what was known, or believed, at the time about events not

2. On 16 December 1941, Stalin told Anthony Eden that the Soviet Union insisted on recognition of its 1941 frontiers: see the transcript of the first talks between Stalin and Eden, 16 December 1941, in O. Rzheshevskii, Stalin i Cherchill: Vstrechi, besedy, diskussii: Dokumenty, kommentarii, 1941-1945 (M.: Nauka, 2004), 39.

3. Francine Hirsch, "The Soviets at Nuremberg: International Law, Propaganda, and the Making of the Postwar Order," American Historical Review, 113, 3 (June 2008): 701-730.

4. On the concept of "moment," see Sebastian Conrad, Dominic Sachsenmaier, eds., Competing Visions of World Order: Global Moments and Movements, 1880-1930s (New York: Palgrave Macmillan, 2007). 
only in Washington, Paris, London, Geneva, and Moscow, but also in Warsaw, Riga, Tallinn, and Helsinki. This means working with the uncertainties and hesitations of the time, even in instances whose outcome now seems as tragically inevitable as the disappearance of Poland and the incorporation of the Baltic states.

The displays of force of 1939 offer a way in to how people thought at the time about international policies of aggression, particularly those of the Nazis and the Soviets, and the rhetoric used to dress them up and justify them. The first part of the present article notes the emergence at the time of new ways of thinking about similarities between the external policies of totalitarian states. However, this is not to invalidate the two major contradictory readings of Soviet aggression, in terms of Realpolitik and Might on the one hand and revolutionary specificity on the other. The second part of the article draws on a series of experiences to demonstrate the existence of an international repertoire in law and in practice in terms of aggression, conflict, and conflict resolution, as well as the tendency to localise and subdivide conflicts and the manner in which the Soviets engaged in such issues and the stance they took. This in turn sheds light on the third part of the article, which explores the rhetoric and justifications used by the Soviets when they entered Poland, sought guarantees in the Baltic states, and attacked Finland. What explanation can there be for the different European reactions to Soviet attacks on Poland, then Finland? The Soviet justifications, drawing on the common stock of international law and earlier experiences, may not have been morally acceptable, but they were politically comprehensible given the context. They did not break with earlier experiences. Rather, the shift came with the attack on Finland, when the revolutionary dimension of Soviet discourse meant that the discourse itself became unacceptable.

The article draws on material from a number of sources. These include diplomatic archives, the archives at the Academy of Sciences and the Ministries for Internal Affairs and State Security, and other publications and press material on the Soviet side, and archives at the League of Nations, the International Anti-Communist Entente, French and British diplomatic documents and diplomatic memoranda, press material, and articles and debates on totalitarianism from Western Europe and the United States. ${ }^{5}$

\section{Was an anti-totalitarian war a possibility in autumn $1939 ?$ Intellectual and political obstacles}

1939-1940 was a key moment in thinking on totalitarianism and its application in external policy. While the first such analyses date from the 1930s, those developed at the outbreak of the war in Poland focused on the use of force and aggression in totalitarian policies and raised the issue of the German-Soviet alliance of

5. The issue of reading Soviet policy in the wider European context is more fully explored in my forthcoming book L'URSS à la frontière (1920-1940): Le politique, l'imaginaire et le quotidien d'un État neuf (P.: Éditions de l'EHESS). 
September $1939 .{ }^{6}$ The twofold shock felt by many intellectuals and activists at the USSR's rejection of the anti-fascist alliance and abandonment of pacifism led them to explore the question of what makes an external policy totalitarian. The first university conference devoted to analysing the nature of totalitarianism was held in Philadelphia on November 17, 1939.' Carlton Hayes, an eminent professor of European history at Columbia and a leading American advocate for the League of Nations whose thinking was influenced by Catholicism, spoke on "The Novelty of Totalitarianism in the History of Western Civilization." ${ }^{\prime}$ He began by referring to the possibility of convergence underlying the peculiarities of mythology - a term he was one of the earliest to use in this sense: "Recent events have disclosed, nevertheless, that peculiarities of mythology are not necessarily divisive when it comes to arranging for a partition of foreign-mission fields." He then underlined the similarities of methods and techniques, acting "behind a mask of plebiscites." He concluded that the novelty of totalitarianism was its "Force against Czechs and Albanians, Poles and Finns!" and "an utter denial of any moral law superior to the might of dictators" in internal and external policy alike.

Another speaker was Hans Kohn, a historian of contemporary nationalism who had studied at the German University in Prague before taking up the Zionist cause in Palestine in 1923, eventually breaking with it and moving to the United States to teach history in 1933. Kohn's paper "The Totalitarian Philosophy of War" made a clear distinction between fascist states and the USSR, arguing that warfare was not a key driving force for the latter. Quoting Mussolini ("War is to the man what maternity is to the woman. I do not believe in perpetual peace; not only do I not believe in it, but I find it depressing and a negation of all the fundamental virtues of man"), he rather described fascist states as those that feed on war, setting their adversaries up as "total enemies," turning heroism, sacrifice and risk into norms for everyday life, and making extreme situations the normal political rule. However, his description and analysis of the Nazi volte-face at the Molotov-Ribbentrop pact could equally apply to the USSR's own brand of totalitarianism, which likewise cut its policies to fit the circumstances:

This flexibility allows the substitution of one enemy for the other most abruptly and enables the leader to direct the almost mystical totalitarian hatred of his

6. See Enzo Traverso's anthology Le totalitarisme: Le $x x^{\mathrm{e}}$ siècle en débat (P.: Éditions du Seuil, 2001). For a distanced historical view of totalitarianism as a concept, see Sheila Fitzpatrick, Michael Geyer, eds., Beyond Totalitarianism: Stalinism and Nazism compared (New York: Cambridge University Press, 2009).

7. The results were published as Proceedings of the American Philosophical Society, 82, 1 (February 1940).

8. Hayes was one of the American experts to take part in drawing up the principles of the League of Nations. He was also a member of the advisory committee of historians working to publish documents recording American participation in the fighting in France. He was US ambassador to Spain from 1942 to 1944 and is held to have played a role in maintaining Franco's neutrality. He became the first Catholic president of the American Historical Association in 1945. His works include The Historical Evolution of Modern Nationalism (1931) and A Political and Cultural History of Modern Europe (Macmillan, 2 vols. 1932-36, rev. ed. 1939). 
followers against the most diverse objects. That explains the startling change in the attitude of the leader of the anti-comintern pact towards communism and the Soviet Union after August 1939.

The Austrian historian and sociologist Franz Borkenau, himself a former Communist, published The Totalitarian Enemy on December 1, 1939 (London, Faber \& Faber, 1940), writing the work after the shock of the Molotov-Ribbentrop Pact and the start of the war when "one of the big surprises of this war [was] to witness Russia, 'the fatherland of all the toilers,' in the role of a military conqueror." For Borkenau, the pact clarified the situation and the parties present brought out the underlying similarities between the German and Russian systems, which he described as "Brown Bolshevism" and "Red Fascism," thereby increasing the war's legitimacy in defending freedom. Borkenau challenged the old label of economic imperialism and underlined the political aspect of such expansionism. He did acknowledge a degree of rationality on the Soviet side, noting their nationalist and strategic objectives: however, he held that the key aspect in both cases was that the will to conquer hid the desire to foment totalitarian revolution in the name of a higher historical necessity.

The notion of convergence re-launched by the pact was also widely held by Trotskyites $^{9}$, as totalitarianism was at the heart of their thought. On September 18 - the day after the Red Army crossed into Poland - Trotsky himself discussed Stalin's propensity for organising referenda for national minorities, following the Goebbels model. Trotsky was one of the few observers to argue that the USSR had joined the war alongside Germany:

War, like revolution, is distinguished by the fact that at a blow it destroys idiotic formulas and reveals the naked reality underneath. "Defense of democracy" is an empty formula. The invasion of Poland is a bloody reality [...]. The Kremlin not only deceived Chamberlain, Daladier, and Beck, but also, and systematically, the working classes of the Soviet Union and the entire world. Some fatuous people and snobs accuse me of being impelled to make horrible predictions out of "hatred" of Stalin. As if serious people allow themselves to be swayed by their personal feelings in questions of historical importance! The inexorable facts prove that reality is more horrible than all the predictions that I made. In entering Polish territory, the Soviet armies knew beforehand at what point they would meet - and as allies, not as enemies - with the armies of Hitler. The operation was determined in its main points by the secret clauses of the German-Soviet pact; the general staffs of both countries were to be found in constant collaboration; the Stalinist invasion is nothing but a symmetrical supplement of the Hitlerite operations. Such are the facts. ${ }^{10}$

However, contrary to the conclusions that some of Trotsky's political allies came to regarding the pact, and despite the virulence with which he himself denounced

9. See Naomi Allen, ed., Leon Trotsky, Writings of Leon Trotsky, vol. 12 (New York: Pathfinder, 1977).

10. Article dated September 18, 1939, ibid, p. 80. 
Stalin's "loyalty to Hitler" and his violent, bureaucratic imperialism, Trotsky nonetheless argued that as a workers' state, albeit degenerated, the USSR should be defended if attacked; he also argued for the objectively revolutionary nature of expansion in Poland and the Baltic states. ${ }^{11}$

The press focused on similarities in method between Hitler and Stalin, sometimes describing them as totalitarian: the aim was to equate brutal policies of Might which relied on sheer brute strength, ignoring the principles of international law and the collective community of nations.

The New York Times published an editorial on October 3, 1939 which argued that

The swift and cold blooded manner in which sovereign nations are summoned one by one to hear what their future status is to be shows Stalin to be something more than an apt imitator of Hitler. His method of intimidation and conquest is quicker and quieter.

The editorial of October 11 proved to be visionary in the light of subsequent events: "Russia's swift invasion of the Baltic sets a new record in the current competition for naked aggression." However, the foregrounding of convergences between Hitler's and Stalin's policies of aggression in autumn 1939 and the theoretical explanations of the two camps - democracies versus totalitarian regimes - did not lead politically to the possibility of war being declared against the USSR as an ally of Hitler. Most political leaders continued to see the USSR as a special case.

The geopolitical vision shared widely by European diplomats, placing Soviet imperial power in the tradition of the Czars, stopped them from seeing the USSR as an ally of Hitler first and foremost when the Red Army invaded Poland. The horizon of events foretold by most commentators was the clash of two competing imperial powers fighting over zones of influence in eastern Europe. Most commentators highlighted the ambiguity of the Soviet position. Telegrams exchanged by Payart, the French chargé d'affaires in Moscow, and Daladier, president of the Conseil in Paris, and by the Quai d'Orsay and the Foreign Office, reflect the intention to leave the range of interpretations wide open to avoid going along with German-Soviet collusion. ${ }^{12}$ The Red Army's invasion of eastern Poland was described as tragic and sinister, but at the same time was seen as an opportunity to widen the divide between Moscow and Berlin in the more or less short term. Consequently, the invasion was not met by any protest. The Western powers refused to read German-Soviet collaboration simply in terms of a military alliance and often invoked the invasion's preventive dimension, crediting Moscow with wanting to stop the German advance as it was beginning to threaten the Romanian border and, from there, the Balkans.

11. Victor Serge foresaw the coming clash between the USSR and Germany, but refused to consider Soviet expansion an objectively progressive element. He held that "the two totalitarian dictatorships are in fact allied against their own populations," La Wallonie (October 21, 1939), Retour à l'Ouest: Chroniques 1936-1940 (Ed. Agone, 2010), 290.

12. Documents diplomatiques français, 1939, 3 septembre-31 décembre, Brussels: PIE-P. Lang, 2002, passim. 
Once the demarcation line between the Germans and Soviets had been laid down on September 22, leaving the oilfields of Galicia and the wheat fields of Volhynia to the Soviets, the withdrawal of Nazi troops was not seen as a tangible sign of an alliance between the USSR and Germany. Rather, it was seen to indicate Stalin's sway over Hitler. Only the Americans thought otherwise. The declaration of September 28 that sealed the friendship between Berlin and Moscow and their new common border shed some light on the situation: Lloyd George declared to the House of Commons that "There is a good deal that we do not know." ${ }^{3}$ However, he added, and Churchill agreed, that there were good grounds not to equate Stalin's action with Hitler's in the division of Poland, as the two men had different visions.

Anti-Communism was likewise a key element in leading public opinion to distinguish between war against Germany and action against the USSR. AntiCommunism was on the rise in 1939. The volte-face of the Molotov-Ribbentrop Pact lifted the ban on all overt expressions of anti-Communism imposed by the policy of collective security and anti-Fascism, led by Soviet diplomats and the Comintern in the mid-1930s. As Raymond Aron noted in his Memoirs in autumn 1939, "my anti-Communism, half-suppressed by my friendships and the need for Soviet support against the Third Reich, burst forth." ${ }^{14}$ Grzybowski, the former Polish ambassador to Moscow, held that

no other totalitarian system has achieved such complete absolutism [...]. The entire Government in the Union of Soviet Socialist Republics is nothing but a system for the preparation within the Soviets of an instrument for revolution and the conquest of Europe..$^{15}$

Théodore Aubert's International Anti-Communist Entente, based in Geneva and with branches in many European countries, intensified its efforts in autumn 1939. The IAE was virulently anti-Communist, the Comintern being its prime enemy; it looked favourably on authoritarian and fascist regimes elsewhere in Europe, such as Franco's Spain, Mussolini's Italy, and Nazi Germany, particularly when the anti-Comintern pact was founded in 1936. However, the IAE considered that Nazi Germany betrayed the anti-Bolshevist cause in signing the MolotovRibbentrop Pact. Aubert's comment was that they had left the anti-Comintern pact for a pro-Comintern pact. In autumn 1939, the IAE sent its corresponding members an account of all Radio Moscow broadcasts and a review of the leading Soviet newspapers, including local papers, covering the Soviet war in Poland and

13. General Sikorski Historical Institute, Documents on Polish-Soviet Relations 1939-1945, vol. 1, London: Heinemann, 1961, p. 57.

14. "Mon anticommunisme, à demi refoulé par mes amitiés et par besoin de l'appui soviétique contre le III ${ }^{e}$ Reich, éclata au dehors," Raymond Aron, Mémoires (P.: Julliard, 1983), 158.

15. Final report presented to the Minister for Foreign Affairs by former Ambassador Grzybowski, Paris, November 6, 1939, Documents on Polish-Soviet Relations 1939-1945, document 69. 
Soviet tutelage in the Baltic states. The aim was to convince the Western powers to join the struggle against the USSR. ${ }^{16}$

The Soviet attack on Finland sparked a new, widely aired wave of openly antiCommunist discourse, as shown by the way the media leapt to Finland's defence and the vote by the Geneva Assembly to exclude the USSR from the League of Nations. The wave of support for brave little Finland fighting against the Soviet giant can also be seen as a way of winning back the moral high ground, a year after Munich. However, the outbreak of the Winter War also followed the anti-Bolshevik model of the civil war period, reviving memories of foreign intervention in 1918-1920. An IAE mission travelled to Finland, describing the country's struggle defending Christian values and civilisation against Bolshevism. Marshal Mannerheim, commander-inchief of Finnish forces during the Winter War, was in fact an honorary member of the IAE board. The IAE representatives were allowed to question Red Army soldiers taken prisoner by the Finns to carry out a survey of living conditions and attitudes in the USSR. ${ }^{17}$ Such denunciations challenged only the Soviet regime, though convergences with Germany were highlighted as a result of the friendship between the two. The German attack on the USSR in 1941 was welcomed by the IAE, which considered that Germany was finally back on track after two wasted years, defending European civilisation against the hydra of revolution.

The rhetoric of the crusades likewise dominated political discourse. While Britain's military experts saw the Soviet attack on Finland as an opportunity to get around neutral Norway and send battalions to keep watch on communication channels and German trade ${ }^{18}$, the plans for the Murmansk landing and for bombing oil wells in the Caucasus, neither of which came to fruition, nonetheless harked back to their earlier strategies for foreign intervention. Anti-Communist activism was clearly encouraged by the revolutionary grounds the Soviets put forward for attacking Finland.

When it came to describing the events of autumn 1939, the ideological struggle against Bolshevism and the geopolitical vision of the USSR as a Russian imperial power and a natural enemy of the Third Reich were major barriers to the political uptake of anti-totalitarian struggle that some activists and intellectuals had already begun to engage in by developing the debate on the Nazi and Stalinist policies of aggression.

\section{Accumulating experiences: a repertoire of modes of aggression and defence against aggression}

Understanding the difference in and disconnect between attitudes to the German and Soviet wars of 1939 means taking account of the accumulation of experiences in the inter-war period. Many of the arguments used by the Soviets to justify their actions in

16. IAE (International Anti-Communist Entente) archives, Geneva Library, vols. 1597 and 1786.

17. Ibid., vol. 3007.

18. Colonel Roderick Macleod, Denis Kelly, eds., The Ironside Diaries 1937-1940 (London: Constable, 1963), 181-197. 
autumn 1939 had already been heard elsewhere and were understandable for people of the day. Many aggressive practices created a feeling of déjà vu, which limited expressions of indignation and calls to resist. The main factor, however, was the tendency to sectorise the war to save the peace, which played against total war in 1939.

Michael Walzer's philosophical treatise on justand unjust wars notes that aggression is the sole name given to crimes between states. ${ }^{19}$ It covers all forms of violation of territorial integrity and political sovereignty, whether the annexation of part of a state's territory, the forced implementation of a satellite regime, or the suppression of a state's independence. International law is a very broad brush compared to criminal law's gradation of crimes involving violations against property or people. Michael Walzer sees this as a positive undertaking. The concept of aggression would crumble if a list of crimes analogous to those in use in criminal law were available. The Nazi leaders were accused and found guilty of aggression at the Nuremberg trials for both the "peaceful" invasion of Czechoslovakia and the "bloody" invasion of Poland.

Yet it seems to me that such a list had indeed begun to emerge in the 1930s, tending to undermine the very concept of aggression. There are indications of this in the League of Nations debates that marked every case of aggression from the Japanese annexation of Manchuria, the Italo-Abyssinian War, and the Spanish Civil War, to Japanese aggression in China, the dismantling of Czechoslovakia, and so on. Each case proved to be unique and led the League of Nations to hedge the issue, introducing differentiated modes of arbitration, conciliation, and sanctions, implying a greater or lesser degree of seriousness and shared responsibility. Attitudes of the day were dominated by the fear of war and the need to appease aggressors. The ultimatum "Your money or your life" was laid down several times in 1938-1939, and the leaders of the states forced to answer often preferred to hand over their resources and territory to avoid bringing war down on themselves and their allies and death on their fellow countrymen. Consequently, the aggressee enabled the aggressor not to pass for a murderer in the eyes of the international community. Until total open war came in 1941, the vision was one of a patchwork of juxtaposed wars. Some were in the Far East, others in eastern Europe; some were national in origin, some were civil wars, while others were caused by the German demand for Lebensraum. Most broke out without war being declared.

The Soviets by no means stood apart from the League of Nations debates; they even played a part in drawing up an international law to combat aggression. It is true to say that the USSR was not represented on all committees, and it was much less involved than the British and French delegations throughout the 1930s. European reservations about involving Bolsheviks too closely in the League's activities echoed Stalin's recommendations to be cautious, his priority being to keep the peace through bilateral relations. For example, though the USSR joined the League of Nations in September 1934, Litvinov was not granted permission for

19. Michael Walzer, Guerres justes et injustes, (P.: Gallimard, 2006) [Just and Unjust Wars: A moral argument with historical illustrations, New York: Basic, 1977]. See Daniel R. Brunstetter, Jean-Vincent Holeindre, "La guerre juste au prisme de la théorie politique," Raisons politiques, 45, 1 (2012): 5-18. 
Soviet delegates to sit on the committee set up on February 24, 1933 to condemn Japan's aggression against Manchuria. ${ }^{20}$ Despite such obstacles, the presence of Soviet diplomats in Geneva meant that the USSR became involved in a number of collective actions to resolve conflict. The Soviet delegates at the League of Nations played a significant role in implementing sanctions when the Italo-Abyssinian War broke out in autumn 1935. They were also active on the Non-Intervention Committee against intervention in Spanish affairs, eventually speaking out against its hypocrisy and inaction. ${ }^{21}$ They agreed to sit on the Consultative Committee on the Far East - formerly the Manchurian Committee - which was reconvened in 1937 when the Second Sino-Japanese War broke out. ${ }^{22}$ They were also the most active support behind Beneš, then in exile in Chicago, in his demand that the League take action when Czechoslovakia was dismantled in March 1939. ${ }^{23}$ Maisky, Soviet Plenipotentiary to Great Britain and member of the Soviet delegation in Geneva, was at that time president of the League of Nations Council.

The prevalent discourses in the 1930s justifying and legitimising interference and intervention in neighbouring states or advocating collective resistance were thus familiar to both the Soviets and their European counterparts and the Soviets played a part in developing a number of key notions. First and foremost, in the context of Japanese aggression, the legal department at the Commissariat for Foreign Affairs started work on a definition of the aggressor, presented by Litvinov in Geneva in February 1933 and later reused by Molotov during tripartite negotiations over assistance alongside the French and British over the course of the spring and summer of 1939. ${ }^{24}$ Against the backdrop of Japanese aggression in the Far East, which the Soviets feared they might have to face alone in 1932-1933, Litvinov's notion of indivisible peace proved useful in rejecting the tendency to localise wars. The notion, which aimed to establish links between conflicts, aggressors, and theatres of war, remained the theoretical underpinning for the Soviet position in 1938, while Moscow denounced the principle of localising war as fascist theory. ${ }^{25}$ Such notions, debated by the legal department and the Service for League of Nations

20. Letter from Litvinov to the PB, October 22, 1934, AVP RF, (Arkhiv Vneshnei Politiki Rossiiskoi Federatsii), 05/14/96/10.

21. On the various stages of the Soviet delegation's involvement in Geneva, see Sabine Dullin, Des hommes d'influences: Les ambassadeurs de Staline en Europe, 1930-1939 (P.: Payot, 2001) [Men of influence: Stalin's diplomats in Europe, 1930-1939, Edinburgh University Press, 2008].

22. The committee's activities are recorded in a large number of files in the League of Nations archives, Geneva, R3607-3612, R3671-R3680. For example, the information available to the members of the Consultative Committee on the Far East includes all the reports on the border incidents between Manchukuo and Mongolia since 1932, League of Nations archives, R3609.

23. Ibid., R3640.

24. Project to define the terms "aggressor," January 14, 1933, note by Egoriev for the Central committee on the work of disarmament and the USSR's position, December 1933, Litvinov to the Politburo, January 25 1933, AVP RF, 05/13/90/11; Litvinov's speech of February 6, 1933, SSSR v bor'be za mir, rechi i dokumenty (M., 1938), 11.

25. See for example the transcript of the meeting of the Scientific Council at the Law Institute (Academy of Sciences), August 25 1938, RAN (Arkhiv Rossiiskoi Akademii Nauk), 1934/1/67, p. 15. 
Affairs at the NKID, were held to be important at a time when the "question of borders and territories," 26 in the words of the diplomats, was of crucial significance to their leaders in the Kremlin. The context did indeed represent a threat to Soviet borders, due to Japanese and German aggressiveness and the recurrent assessment of neighbouring countries as military parade grounds for the aggressors. ${ }^{27}$

Every instance of international aggression gave rise to analyses in Moscow, based on sources and publications from the League of Nations and the states in question. The analyses were carried out not only by the diplomatic service but also by various research institutes with expertise in international issues. ${ }^{28}$ These institutes were far more than propaganda outlets bringing the decisions taken at the highest level to the masses: they worked with various political and administrative bodies with international responsibilities, such as the Central Committee, the Politburo, the Comintern, and the People's Commissariats, particularly for Foreign Affairs. They also played a significant role in outlining the key issues of the day. ${ }^{29}$ Significant players in the debate on war and aggression included the Institute of World Economy and Politics, founded in April 1925 as part of the Communist Academy and headed by $\operatorname{Varga}^{30}$ since the late 1920s, and the Law Institute, under the leadership of Pashukanis until 1937 and then Vyshinsky, who oversaw the creation of a section specifically devoted to international law in $1938 .{ }^{31}$ The section brought together academic legal specialists and researchers from Moscow and the provinces and practitioners of international law, particularly members of the NKID law department. ${ }^{32}$ One of its most prominent members, Ilya Trainin, published a

26. "Pogranichno-territorial'nyi vopros," Dokumenty Vneshnei politiki SSSR (1930-1938), vols. 19-21 (M., 1976), DVP SSSR, 1939 god, t. XXII, vol.1 (M., 1992), passim.

27. See for example the Russian "platsdarm," borrowed from the French "place d'armes," which was widely used in Soviet rhetoric.

28. On international expertise in the USSR, see Oded Eran, Mezhdunarodniki: An Assessment of Professional Expertise in the Making of Soviet Foreign Policy (Tel Aviv, 1979).

29. See for example Karl Radek's informative analysis of the Italo-Abyssinian War, which was debated at a meeting of the Institute of World Economy and Politics. The analysis was detailed enough to serve as an aide-memoire for the leaders of the CC and was also used as a guide for agitprop aiming to explain and legitimise Soviet action on the Abyssinia question: "Italoabissinskii konflikt," October 3, 1935, RAN, 354/2/184, 43 p. See also RAN, 354/1.

30. Eugen Varga was a Hungarian economist and one of the leaders of the Hungarian Revolution of 1919. He began working for the Comintern in Moscow in 1920 and joined the group in charge in 1928. He headed the Institute of World Economy and Politics from October 1927 on. Letters dating from the 1930s reflect his special relationship with Stalin: see the Academy of Sciences (RAN) archives, Moscow, collection 1513, op. 1, d. 198 (1513/1/198).

31. The Institute of Soviet Construction (institut sovetskogo stroitel'stva), which had been part of the Communist Academy since 1925, was renamed the Institute of Soviet Construction and Law in 1936, when it joined the Academy of Sciences. It became the Institute of Law in 1938. RAN, collection 1934, istoricheskaia spravka.

32. Members of the section included Il'ia Trainin, professor and researcher at the Communist Academy since the 1920 s, B.A. Landau, jurist at the Sverdlovsk Institute, who took over the periodical review of foreign literature (books and journals) and the corresponding section in the journal Sovetskoe gosudarstvo in 1938, and Vladimir Egoriev of the NKID law department, spiski chlenov Sektsii mezhdunarodnogo prava, RAN, 1934/1/62, p. 1-7. 
highly significant book entitled The Defense of Peace and Criminal Law (1937), which criticised the League of Nations for failing to create an international criminal court to punish aggressors ${ }^{33}$. The section of international law's work programme for 1938-1939 focused on the concept of territory in contemporary international law, particularly the practice of referenda and the regimes of border territories, modes of aggression, and conflict prevention and resolution. ${ }^{34}$ Similarly, reading articles published in 1937-1939 in Mirovoe khoziaistvo i mirovaia politika, the excellent, well-informed journal published by the Institute of World Economy and Politics, it becomes clear the extent to which Soviet leaders drew on the modes of aggression against Abyssinia, China, and Czechoslovakia as a concrete source of inspiration, despite official denunciations. They include descriptions of how to stoke provocation and organise incidents, the pretexts given by aggressors for launching armed operations and invading foreign territories in the case of Abyssinia and China, details of how Czechoslovakia was dismantled, the annexation of Memel, and Germany's efforts to undermine Danzig..$^{35}$ The increasingly common practice of violating state borders without declaring war also caught the eye of Soviet experts. The German jurist Rupert von Schumacher's book Der Raum als Waffe (Berlin, 1935), which explored the issue, was reviewed, and pamphlets and books were published on the question, including a book on Czechoslovakia (Gospolitizdat, late 1938) and another in early 1939 on the Ukrainian question raised by the Germans, Hungarians, and Poles over Carpathian Ruthenia and Ukraine. ${ }^{36}$ Lemin, who was one of the most prolific researchers at the Institute of World Economy and Politics and a keen reader of everyone from Toynbee to German Nazis, wrote two enlightening articles on the second imperialist war in 1939. ${ }^{37}$

A number of ideas arise from the Soviet harvesting of information and analysis. First and foremost among them is the powerful notion that the practices of colonialism were now being applied to Europe. Rome based its entire justification for the invasion of Abyssinia following the Walwal incident on the right of a colonial power to intervene when it came to guaranteeing public order in outlying territories

33. Francine Hirsch, "The Soviets at Nuremberg: International Law, Propaganda, and the Making of the Postwar Order," American Historical Review, 113, 3 (June 2008): 701-730.

34. Transcript of the Scientific Council meeting to discuss the programme on international public law, August 25, 1938, RAN, 1934/1/67, 40 p.

35. Border incidents were a regular occurrence as tensions rose between the government of the free city and the Polish authorities: examples include the Kalthof incident on the border between Danzig and eastern Prussia on May 20, 1939 and the death of a Polish border guard on July 20, 1939. The declaration of war on Poland on September 1 was again based on a border incident.

36. The authors are respectively F. Kozo, Chekhoslovakiia (Gospolitizdat, 1938) and Z. Lippai, Bor'ba imperialistov $v$ Dunaiskom basseine (Gospolitizdat, 1939). Both also contributed articles on the same subjects to Mirovoe khoziaistvo i mirovaia politika.

37. "Problemy vtoroi imperialisticheskoi voiny," Mirovoe khoziaistvo i mirovaia politika, $\mathrm{n}^{\circ} 1$ (1939): 29-44, and $n^{\circ} 3$ (1939): 87-104. I. Lemin was a historian specialising in international relations and Great Britain. He joined the VKP(b) in 1918 and began working with the Institute of World Economy and Politics in 1933. 
where it was a problem, in this instance because the Negus was unable to maintain order. The Italian High Commissioner in East Africa made a proclamation to the inhabitants of Tigre on October 3, 1935, that "[t]o avoid your lands being damaged by war and to help the numerous inhabitants of Tigre and other regions who have

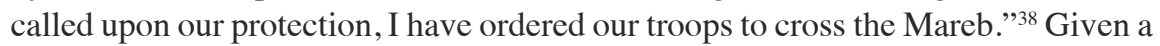
certain number of analyses favourable to Italy's civilising mission in Ethiopia, the definition of the aggressor drawn up in 1933 based on Litvinov's project was not applicable outside Europe. The simple fact of an army unit crossing a border within a colonial possession could not necessarily be considered an act of aggression if the border was little marked on the ground and if incursions, raids, and bandits threatened the lives and property of the local population. One much-quoted example was the far reaches of the British empire, where expeditions were often carried out across borders to maintain public order. The same argument was made when Japan invaded Manchuria, then China: Japanese and Korean inhabitants needed protecting from Chinese exactions. European supporters of China in 1937-1938 devoted their efforts to highlighting China's fast-paced modernisation and the ability of its leaders to keep control over its entire territory and guarantee public order.

The specificity of the colonial situation was challenged when the same methods were used in Europe and China in 1939: the Japanese and German aggressors frequently used border incidents as pretexts, and Germany created a protectorate in the case of Bohemia and Moravia. Lemin described Bohemia in March 1939 as a colony of German imperialism, adding that "the regime that has been put in place in the country is one that was until now 'common' only in distant colonies in Africa or Asia." ${ }^{39}$

The Soviet analysis that colonial methods were being imported into non-colonised regions shaped the USSR's public diplomacy, which, until the Molotov-Ribbentrop Pact and the summer of 1939 , focused on the need to protect the sovereignty and independence of smaller and medium-sized states facing the threat of Fascist aggression. It should be borne in mind that many advocates of collective security saw the Soviets as the best defenders of small states whose existence was threatened by the major powers ${ }^{40}$ However, it should also be added that the extent to which this was seen as a good thing very much depended on geographical proximity to the USSR. It was much less present in those states bordering the USSR: for them, the protection offered by their larger neighbour was unwelcome, even dangerous.

38. Nicolas Basilesco, La SDN devant les conflits internationaux et spécialement devant le conflit italo-éthiopien (Bucarest, 1936).

39. I. Lemin, "Problemy vtoroi imperialisticheskoi voiny," Mirovoe khoziaistvo i mirovaia politika, $\mathrm{n}^{\circ} 3: 96$.

40. As seen against the backdrop of events in Geneva from the disarmament conference to Munich, Soviet policy appeared to be at pains to defend those states excluded from important decisions by the major powers. One significant indicator was Litvinov's remark to Krestinsky on June 23, 1932, that "the smaller powers, especially the Scandinavians, are very irritated by the procedure but dare not show it. This explains in part the applause I received yesterday at the commission, because the smaller powers recognised my speech as their megaphone," Dokumenty Vneshnei Politiki SSSR (M., 1969) vol. 15, n² 260, 382. 
It must be said that the Soviet analysis did distance itself from the protection of national minorities - a position that it had made its own in the 1920s and that was used abundantly by the Germans and Hungarians in 1938-1939 - before eventually returning to it in September 1939. I shall illustrate this point with the example of the Ukraine.

The Ukrainian question became a burning issue across Europe for the first time in the post-Munich period. ${ }^{41}$ Articles on the Ukraine were printed not only in the Soviet press and in papers targeted at the Russian and Ukrainian diaspora, but also in European journals and newspapers from both ends of the political spectrum. In France, for example, December 1938 and January 1939 saw the publication of articles on the Ukraine in Le Temps, Le Figaro, Le Matin, L'Illustration, Je suis partout, Gringoire, and Politique étrangère. On November 21, 1938, Paris Soir published an article commemorating the thousandth anniversary of the marriage of Anne of Kiev and Henri I of France, telling readers that "Nazi propaganda has made [the Ukraine] its new goal." The headline on the cover of the Swiss Courrier de Genève for December 27, 1938 was "Will the Ukraine recover its independence some day?"42 The ethnographic map of the Ukraine defended by the standardbearers of the Ukrainian national ideal at the post-war conferences was all over the newspapers. The new wave of interest in the Ukraine came about because of the initial dismembering of Czechoslovakia following Munich and Hungarian and Ukrainian claims to Ruthenia, once part of the Hungarian side of the AustroHungarian empire that became part of Czechoslovakia under the Treaty of SaintGermain-en-Laye. Hungary annexed the Hungarian regions of southern Slovakia and western Ruthenia around Uzhgorod, Mukachevo, and Beregovo at the Vienna arbitration of November 2, 1938. This marked the beginning of an orchestrated German campaign debating the Ukrainian claim to the rest of Ruthenia, which might become a new expanse of the Ukrainian territories under German protection, bringing with it the lands of eastern Galicia and Volhynia taken from Poland, or even the Soviet Ukraine in the long run. The campaign, encouraged by Berlin, lasted until Hungary annexed Ruthenia the following March: this option won out over the potentially autonomous Carpatho-Ukraine as a German protectorate, which Voloshyn and Révaý's short-lived government in Khust had campaigned for. ${ }^{43}$ Germany also stepped in to protect the Slovaks against the Czechs in early 1939. Soviet observers highlighted the importance to Germany of undermining internal politics by recruiting agents, informants, and activists in favour of the German and/or Nazi cause throughout eastern Europe: those recruited were mainly Germans,

41. The 1933 famine had given rise to a first wave of media interest in the Ukraine across Europe, but only in the anti-Soviet and anti-Communist press; it was less widely debated than in 1938-39 due to the embarrassed silence of the leaders of anti-Fascist opinion.

42. See the very comprehensive international press review on the Ukraine question compiled by the IAE in the IAE archives, vol. 1674.

43. On the history of Sub-Carpathian Ruthenia/Transcarpathian Ukraine, see Paul Robert Magocsi, A History of Ukraine, University of Washington Press, 1996, and Valentina Mar'ina, Zakarpatskaia Ukraina v politike Benesha i Stalina (M.: Novyi Khronograf, 2003). 
Slovaks, and Ukrainians, but also included others involved in far-right politics. The Western diplomats based in Czechoslovakia in the post-Munich period all noted that German-Bohemians, Slovaks, and even Ruthenians were being instrumentalised to organise support for German demands from within. ${ }^{44}$

The protection of minorities, which could pose a threat to the integrity of the USSR in the long run, was closely observed by the Soviets, and was denounced in the press. Stalin spoke ironically at the eighteenth Party congress on March 10, 1939 of "madmen [...] who dream of annexing the elephant, that is, the Soviet Ukraine, to the gnat, namely, the so-called Carpathian Ukraine." The Soviet press wrote about German "comedies." 45 The choice made by the Soviets in spring 1939 was thus to present themselves as defending the integrity and independence of small and medium-sizes states in eastern Europe, repeating that the Bolsheviks had helped them into existence in 1920-21.

Over the course of the spring of 1939, Soviet analyses of the impending second imperialist war were based on an updating of the theory of just and unjust wars - then fairly new terminology in Soviet writing. ${ }^{46}$ Just war arose from the convergence of class war and national wars of de-colonisation in small and medium-sized European countries under the rule of fascist colonisers. This theorisation offered the advantage of including anti-fascist activism and the revolutionary ideal, while re-stating the right of peoples to self-determination in the face of imperialist threats.

\section{Reversal in continuity - The Soviets in July-December 1939 and the use of accumulated experience}

Maisky, Soviet Plenipotentiary to Great Britain and member of the Soviet delegation at the League of Nations, sent a letter to Litvinov in November 1935, shortly after the outbreak of the Italo-Abyssinian War. He began by evoking the considerable decline in France's reputation in Geneva, before adding, "there remain only two great powers with immaculate reputations in the mind of the League of Nations: England and the USSR." ${ }^{47}$ This letter, though highly self-satisfied in tone, does reflect a genuine state of affairs. Following Litvinov's reinvigoration of Soviet diplomacy and the Comintern's Frontist turn of 1934-1935, the Soviet Union had come to be seen by some parties devoted to peace, progress, and anti-fascism as positive supporters of League of Nations policy, while Soviet diplomats and experts alike helped shape international law on aggression and legitimate self-defence.

44. See George F. Kennan, From Prague after Munich: Diplomatic Papers, 1938-1940 (Princeton, 1968).

45. See for example F. Kozo, "Zavershenie miunkhenskoi raspravy nad Chekhoslovakiei," Mirovoe khoziaistvo i mirovaia politika, $\mathrm{n}^{\circ} 3$ : 104-108.

46. However, even Marx and Lenin could yield to normative moral arguments in their own analyses: Marx did so in his attitude to the Franco-Prussian War, Lenin in discussing the violation of Belgian neutrality. See Walzer, Guerres justes et injustes, 149 and 434.

47. Maisky to Litvinov, November 25, 1935, AVP RF, 010/10/48/7. 
At the same time, the repertoire of types of discourse and practices used to legitimise aggression that had sprung up over the course of the 1930s was familiar enough to serve Stalinist policy should the need arise, it being was keen to make the most of a tricky situation, fraught with danger and opportunity.

The Soviet leadership had two main objectives in mind in the summer of 1939: guaranteeing the country's safety, extending its gaze to neighbouring states that, though reluctant, might need the USSR's protection, and avoiding becoming embroiled in the "second imperialist war." This required effective guarantees of "assistance" and finding ways to be a non-aggressor.

The first notion to appeal to the Soviets was that of indirect aggression, which can provide legitimate grounds for taking preventive guarantees. The definition of aggression put forward by Litvinov in the London Protocol of July 3-4, 1933 included five points: the declaration of war, invasion, armed attack, naval blockades, and "support accorded armed bands which are organized on its territory and which shall have invaded the territory of another State; or refusal, in spite of the demand of the invaded State, to take on its own territory all steps in its power to deprive the bandits aforesaid of all aid or protection." 48 The last point could be seen as a concession to the right to colonial-style interference in the case of a state unable to maintain public order. However, for Litvinov and the Bolsheviks, it meant something else. It was about the reality of the situation along the Soviet borders, where buffer zones - some demilitarised - had had to be established after the civil war, together with concrete conciliation procedures with neighbouring states to try and bring an end to altercations and armed skirmishes. This had then led to the signature of bilateral non-aggression pacts, followed up by the London Protocol. The Bolshevik stance, shaped by the feeling of being encircled by capitalists, is apparent in the use of the word "refusal" to co-operate. The term suggests ideological or political mistrust, even hostility. Molotov then expanded on this Bolshevik addition to international law in July 1939 during the tripartite negotiations with France and the UK on mutual assistance. The mechanism of assistance was supposed to come into effect in instances of "direct or indirect aggression against one of the European countries whose defence of independence or neutrality is held to be indispensable by one of the three signatories." Molotov suggested that indirect aggression should be defined as "an internal change or a change of policy favourable to an aggressor" and put forward a list of countries potentially affected by such indirect aggression: Estonia, Finland, Latvia, Poland, Romania, Greece, and Belgium. ${ }^{49}$ He referred to two precedents to justify his proposal: the first, which should have been defined as an indirect aggression at the time, as Beneš and the Soviets had suggested, was when Emil Hácha, president of Czechoslovakia, was threatened into agreeing to the

48. The Convention for the Definition of Aggression, July 4, 1933, DVP SSSR, t. XVI (M.: Politizdat, 1970), 403-406. See also Alphonse Schwartz's reaction published shortly after the event, Les systèmes pour la paix et le protocole de Londres des 3 et 4 juillet 1933 sur la définition de l'agresseur (University of Poitiers, Law Faculty, 1934) 59-60.

49. Molotov's response to the latest Franco-British proposals, July 3, 1939, God Krizisa, 1938-1939, vol. 2 (M.: Gospolitizdat, 1990), 80-81. 
occupation of his country as a protectorate on March 15 that year. The second was the Nazification of Danzig, which left little doubt as to the situation's "peaceful" outcome. The British representatives refused the notion of indirect aggression, however, since it could potentially justify interfering in the internal affairs of a sovereign nation: Estonia and Latvia had signed pacts of non-aggression with Germany in early June.

In fact, Soviet diplomacy had already shared its understanding of the guarantee of assistance with neighbouring countries when Litvinov offered the Baltic states a unilateral guarantee in case of aggression on March 28, which stated that the USSR "cannot remain a passive bystander in the case of economic or political domination by Germany or in the case of territorial concessions or cessions." 50 Romania had been given a similar warning on March 27 after signing an economic agreement with Germany: the USSR "cannot remain a passive bystander in the case of an aggressor state's domination of Romania and the creation of bases near our border or in the Black Sea ports." ${ }^{51}$ The Soviet message was mixed: the rhetoric of offering protection to small and medium-sized states against fascist aggression, characteristic of earlier years, could lead to the argument that intervention was necessary in neighbouring states. The Soviets could argue that they were entering small states eager to stay of out of the conflict on preventive grounds if the state in question could potentially be used for military purposes by a presumed adversary. This was the argument the Soviets used on the Baltic states and Finland. The idea was not new: it had been explored by Hegel and was at the heart of Bethmann Hollweg's argument justifying the violation of Belgian neutrality on August 4, 1914..$^{52}$

The issue of assistance to neighbouring countries did not fundamentally change even following the Molotov-Ribbentrop Pact. The secret protocols were underpinned by the notion of exclusive zones of influence. ${ }^{53}$ Stalin's demands in eastern Poland and the Baltic were intended to block all possibility of indirect aggression by providing a military presence and, in the medium term, to bring about complete political alignment with Moscow. This appears very clearly in Stalin's discussions with Baltic leaders in late September and early October 1939, when the latter were forced to sign pacts of mutual assistance and to accept Soviet military

50. These declarations followed Germany's Memel ultimatum that Lithuania was forced to accept. DVP, vol. 22, book 1, 231-232.

51. The economic agreement signed on March 23 gave Germany the monopoly in exploiting Romanian oil. Litvinov held it to be "an agreement to enslavement": Litvinov to Stalin, March 27, 1939, ibid., p. 230.

52. Hegel argued that war was just if it guaranteed the security of the state: preventive wars could be necessary against small neighbouring states coveted by a rival power. See John A. Moses, "La théorie de la guerre juste dans l'Empire allemand (1871-1918)," Mil neuf cent. Revue d'histoire intellectuelle, 1, 23 (2005): 149.

53. Sergei Sluch, "O nekotorykh problemakh diplomaticheskoi bor'by v kanun vtoroi mirovoi voiny," Politicheskii krizis 1939 g. i strany Tsentral'noi i Iugo-Vostochnoi Evropy (M.: RAN, 1989), 98-99. 
bases. ${ }^{54}$ The Baltic leaders tried to defend themselves by raising deliberately naive questions: what risk was there to their neutrality and what enemy was the USSR proposing to protect them from, since Germany was now a friend and it seemed highly unlikely that Britain would attack them? However, Stalin and Molotov's thinking as a whole remained anchored in the experiences of Czechoslovakia and Danzig that same year: some kind of collateral was necessary as a guarantee, since it was always possible that the enemy might try some underhand tactics and only total control could guarantee security. It should be borne in mind that the political perspective of the "total security state" dominated all sectors of activity in the USSR under Stalin at that time..$^{55}$

Behind the first ultimatum to Estonia was the Orzel incident, involving a Polish submarine, held in port in Tallinn according to the law of neutrality, but which left for Britain on September 17. Moscow denounced Estonia's neutrality as a fabrication and openly doubted the country's ability to control its coastline. It then proposed a form of "co-operation among neighbours" to defend the Baltic coast against aggressors, presenting the plan as the crowning achievement of twenty years of good relations, following the treaties of 1920 and the non-aggression pacts of 1932. Alongside the inevitable reference to Peter the Great's "Baltic window" and his foundation of Paldiski, Molotov and Stalin rooted their demands in the contemporary state of affairs and the state of war in Europe. Stalin saw his request for bases along the coastline as analogous to British demands for aerodromes and submarine ports in Sweden and their offer to purchase two of the country's islands. Antanas Smetona, president of Lithuania, saw the Kaunas ultimatum as fundamentally similar to the German ultimatums, particular the demand for Klaipeda in January: "The Soviet conception of law is similar to that of the Axis." 56

The Soviets made twofold reference to mutual assistance in discussions with the Latvians. The first of these was negative, referring to the pact with Czechoslovakia. Munich and March 1939 were two key precedents for the Soviets, demonstrating what they had to avoid. Moscow identified a number of elements that were necessary for a pact to be effective. In military terms, an effective pact required a simplified bilateral procedure rather than international guarantees, as well as military presence in the territory to be protected, or, at the very least, easy access to it. The pact also had to include the notion of indirect aggression. In the case of aggression against Czechoslovakia, however, the mechanism of assistance had been rendered inoperable first by the Munich conference, then by Slovak independence and Emil Hácha's agreement to become a protectorate.

The second reference was positive, at least from the Soviet point of view: the mutual assistance pact with Mongolia. It raised hackles in Tallinn, Riga, and Kaunas, as the Baltic leaders did not want their futures to be compared to that

54. E. Krepp, Security and non-aggression: Baltic States and USSR Treaties of non-aggression, Problems of the Baltic III (Stockholm, 1973).

55. Silvio Pons, Stalin and the inevitable war: 1936-1941 (London: Frank Cass, 2002).

56. Senn, Lithuania 1940, 88. 
of Mongolia, a country with no international existence that was the USSR's first satellite state. However, military co-operation between Mongolia and the Soviets and the presence of the Red Army on Mongolian territory were a positive example for the Kremlin, since they had led to victory over the Japanese Manchurian army in the conflict sparked by the Khalkhin Gol incident. ${ }^{57}$ The Mongol model was called on several times over the course of 1939-1940: Mongolia's alignment and satellisation went hand in hand with the preservation of formal sovereignty and territorial integrity, for which the Mongols and the Red Army had fought the Japanese. Neither Czechoslovakia nor Poland were able to say the same.

The other crucial issue for the Kremlin was to stay out of the "second imperialist war." It seemed possible: after all, the Molotov-Ribbentrop Pact was officially only a pact of non-aggression, as all the clauses relating to territory were kept secret. However, Soviet troops entering eastern Poland would undermine the subterfuge and reveal the Nazi-Soviet alliance against Warsaw. This meant running the risk of war with France and Britain. On September 10, Molotov informed Schulenburg, the German ambassador in Moscow, that the Red Army had been caught unawares by the Wehrmacht's lightning successes. Four days later, he informed Schulenburg that the Red Army was now prepared, but was waiting for Warsaw to fall before crossing the border. ${ }^{58}$

The principal argument justifying the Red Army's entry into Poland was the power vacuum and the ensuing chaos. The note sent to the Polish ambassador is unequivocal:

the Polish State and its Government have, in point of fact, ceased to exist. In the same way, the Agreements concluded between the USSR and Poland have ceased to operate. Left to her own devices and bereft of leadership, Poland has become a suitable field for all manner of hazards and surprises, which may constitute a threat to the USSR. ${ }^{59}$

A note sent to all the ambassadors in Moscow on September 17 again stated that the Red Army's presence in Poland did not invalidate the USSR's neutrality in the war. The Soviets also prepared the ground for the troops to cross the border as peacefully as possible. The NKVD sent operational groups on special missions to Poland in late August 1939 to recruit local informants and agents who helped the units across the border rivers on the day of the invasion, taking the Polish border guards by surprise and sabotaging forts. Diversionary units consisting of locals and

57. Account by the Latvian Minister of Foreign Affairs, Munters, of talks with Stalin and Molotov, October 2, 1939, Polpredy soobshchaiut... Sbornik dokumentov ob otnosheniiakh SSSR s Latviei, Litvoi i Estoniei, avgust 1939g.-avgust 1940g. (M.: Mezhdunarodnye otnosheniia, 1990), 75-77.

58. For a record of talks between Molotov and Schulenburg, see the Politisches Archiv des Auswärtiges Amtes, vol. 8, 34-35 and 47, quoted in Meltiukhov, Upushchennyi shans Stalina, 90-91.

59. DVP $1939 \operatorname{god}$ (M.: Mezhdunarodnye otnosheniia, 1992), t. 22, vol. 2, doc. 597, 96. 
agents from the USSR also fought the Polish army from within.$^{60}$ One of the main propaganda arguments advanced in the wake of the advancing Red Army was the need to protect the lives and property of the people of eastern Poland. The theme of restoring public order went hand in hand with measures taken to keep the troops in check. They were forbidden to confiscate grain or livestock, for example, and had to buy them from the local population. Two measures were taken to avoid thefts and pillaging, turning the Red Army soldiers into eager consumers. They were paid one to three months' salary in advance and an edict was issued establishing parity between the rouble and the zloty, with the consequence that traders in eastern Poland were forced to sell their wares very cheaply. ${ }^{61}$ Such assistance from abroad was presented as legitimate, since it put an end to civil war. At a local level, the Red Army's entry into Poland sparked the pillaging of properties and revolt against the authorities of the Second Republic. The revolts in Skidel and Grodno were brutally crushed until the arrival of the Soviet soldiers put a stop to the repression.

The early days of the Second World War were shaped on the side of democracy by the counter-example of Japan's war in China, marked by exactions, massacres, rape, and bombing against civilian populations ${ }^{62}$. When France and Britain declared war on September 3, they specifically stated that their armies would not bomb civilian populations. The Soviet Union likewise played the card of a "civilised" army operation the same month. Only once the division of Poland was complete and Belorussia and western Ukraine had been integrated into the Soviet republics did violent repression against the Polish population begin.

The arguments of the need to restore public order and protect the local population were largely heeded by the Western powers, as was the lack of any declaration of war by the USSR, which remained officially neutral. While the British and French decision to declare war on Germany had been immediate, their attitude in the case of the USSR's invasion of Poland was "wait and see." The Polish ambassador to Moscow (until September 16) argued in front of Sir William Seeds that Russia had no intention of attacking Poland. Diplomatic relations were not broken off even after the invasion, and Paris and London simply asked the Soviets to explain their behaviour on September 20. The arguments put forward by the Soviets in autumn 1939 in the cases of Poland and the Baltic states were part of the shared heritage of 1930s Europe: security, assistance, protection.

The USSR once again brought up the issue of defending oppressed national minorities in Ukraine and Belorussia as it was preparing to send the Red Army

60. Organy Gosudarstvennoi bezopasnosti SSSR v Velikoi Otechestvennoi voine. Sbornik dokumentov, vol. 1, book 1: noiabr' 1938-dekabr' 1940 (M.: Akademiia FSK, 1995), 70, 74, 79,85 .

61. Directives issued by the NKVD in the USSR, Ukraine, and Belorussia on how work was to be organised in liberated districts, September 15, 1939, ibid., p. 79; see also Jan T. Gross, Revolution from Abroad: The Soviet Conquest of Poland's Western Ukraine and Western Belorussia (Princeton University Press, 1988).

62. See Iris Chang, The Rape of Nanking: The Forgotten Holocaust of World War Two (New York: Basic Books, 1997) [Iris Chang, Le viol de Nankin, P.: Payot, Petite Bibliothèque, 2007]. 
over the border into Poland. The troops crossed the border with the idea widely propagated by Soviet propaganda in liberated areas - that entering Poland was a means of bringing together the "blood brothers" of Ukraine and Belorussia, separated by an unjust border since the Treaty of Riga. It enabled the Soviets both to take revenge on Piłsudski's imperialism ${ }^{63}$ and to complete the national projects left in abeyance following the First World War. The Ukrainian national question and its ethnographic map were no longer mysteries to Europe following the media campaign earlier that year. Furthermore, the idea of protecting local populations against the German threat despite the Molotov-Ribbentrop pact did feature in the declarations of conscripts who took part in the Polish campaign. While the revolutionary perspective was heard on the ground - the aim was to free the Ukrainians and Belorussians from landowners and the Polish bourgeoisie ${ }^{64}-$ it was largely absent from the discourse directed at international opinion and only men like Trotsky and Théodore Aubert were in a position to point out its significance. Similarly, when the Baltic states were placed under tutelage during the winter of 1939-1940, there was nothing to suggest revolutionary motives or a desire for political and economic interference. The sole grounds for the action appeared to be military objectives for the sake of security.

The case of Finland was very different. The policy planned in Moscow was similar to that targeted at the Baltic states, but it failed: Helsinki turned down the pact of mutual assistance, refusing to grant the USSR a thirty-year lease on the Hanko peninsula ${ }^{65}$ or to hand over a strip of land north of the border extending across the Karelian isthmus from Vyborg to Lake Ladoga: doing so would neutralise the Mannerheim line. Finnish concessions over the gulf islands demanded by the Soviets in the April were not enough. Erkko, the Finnish Foreign Affairs Minister, stated on November 1 that he considered the Soviet demands to be Russian imperialism. Talks were then held again from November 3 to 13, with Stalin himself intervening in the negotiations on November 4. However, Finland's stance of resistance was supported by Britain, France, and the country's Scandinavian neighbours and her position remained unchanged. ${ }^{66}$

The Soviets thus turned to their well-oiled arguments on legitimate self-defence to attack Finland. A border incident - real or staged - in the village of Mainila on the Karelian isthmus on November 26 was presented as Finnish provocation, and

63. Piłsudski died in 1935, but as victor in the Polish-Soviet War of 1920 and founder of the Polish state, he was still seen as symbolising Poland's territorial ambitions to the east. The so-called Pilsudskist bandits were targeted by the Soviet political police throughout the inter-war period.

64. Pravda, September 14, 1939; Pogranichnye voiska, 1939-1941 (M.: Nauka, 1970), 237; poster by Viktor Koretski, printed in four languages with a run of over 800,000 copies, featuring a quotation by Stalin: "Our army is an army of liberators."

65. The Soviet plan was to build a naval base and coastal defences and to station an infantry regiment, two anti-aircraft artillery divisions, two air regiments, and a tank batallion there - a total of five thousand men.

66. See O. Manninen and N.I. Baryshnikov, "Peregovory oseniu 1939 goda," in Rzheshevskii, Vekhvilainen, eds., Zimniaia Voina 1939-1940, 113-130. 
Moscow demanded the withdrawal of all Finnish troops from a zone extending twenty to twenty-five kilometres from the border. The Finnish reaction was to throw doubt on the presence of Finnish units during the incident in question. They suggested calling on the border commission to settle the question and decide whether the border zone should be neutralised on both sides. Moscow took this as a refusal and claimed that it freed the USSR from its obligations under the non-aggression pact. A fresh spate of border incidents gave the Soviets the excuse they needed to break off diplomatic relations on November 29.

Moscow then returned to the earlier arguments from the civil war period, when Red and White Finns fought over Helsinki, and adopted a revolutionary strategy targeted at persuading both the local population and international opinion. A Finnish popular government was formed on November 13. Kuusinen, a civil war veteran and one of the leaders of the Finnish Communist Party who had become secretary to the Comintern executive committee, was appointed president; his ministers were chosen from Finnish communists in exile in the USSR. A Finnish popular army was formed from Finns and Karelians serving in the Leningrad military region: by November 26, it was 13,405 men strong. The mutual assistance pact refused by Helsinki was signed, the USSR ceded 70,000 square kilometres of territory in eastern Karelia to the Democratic Republic of Finland, and the legal Finnish government was denounced as bourgeois and therefore illegitimate.

Operations began on November 30. Finland appealed to the League of Nations; the League's Council called the Soviet and Finnish delegates to Geneva for talks on December 12. The Soviet government refused the invitation, sticking to its version of events and pointing out that they were not at war with the recognised government of the Democratic Republic of Finland, with which the USSR had signed a pact of mutual assistance. The League voted to expel the USSR on December 14 based on its attack on Finland and the violation of all signed agreements. The conflict, which affected the safety of Leningrad, was the first since the Molotov-Ribbentrop Pact to adopt the civil war rhetoric of class solidarity and revolutionary expansion through the Red Army. Europe's response was quick and stinging, although its military scale remained very limited.

\section{Conclusion}

The USSR found a way not to enter the Second World War in 1939, while waging war on its own account. A compelling argument can be made that the lack of reaction to the Soviet aggression of Poland and its demands on the Baltic states in autumn 1939 arose from the ambiguous situation created by the pact and from the splintered vision of conflict that was characteristic of the inter-war period. Those who saw the war in terms of the need to resist two forms of totalitarianism in 1939 were few and far between. In Moscow, theoreticians and practitioners of international relations and law shared much in the way of reading and experience with their European counterparts when it came to observing modes of aggression 
and conflict resolution. Political differences and ideological struggles across Europe did not hinder the formation of a transnational repertoire of types of discourse and practices understood and called on by the USSR and other countries. On the other hand, Moscow did maintain specific policies marked by revolutionary convictions: only when these were publicly held up to legitimise warfare did they meet with overtly hostile reactions, as shown by the Winter War.

(traduit du français par Susan Pickford)

Université de Lille 3

sabine.dullin@univ-lille3.fr 